\title{
AGGLOMERATION PROCESSES OF BALANCED DEVELOPMENT OF SUBURBAN AREAS OF LARGE UKRAINIAN CITIES
}

\author{
(C) Yatsenko V., 2020
}

The article is a result of an analytical research on development of relations between the city and suburban area. An attempt to define main factors that may be included into a future strategy of balanced development and to avoid a number of problems in the organization of group forms of settlement in the big cities' influence zone. The decentralization processes in the governance system constitute the social and economic potential for creation of a system of common interests in development, and not for destruction of both cities and suburban area.

The research materials analyze the current state of affairs of urban planning activities in Ukraine, in particular, peculiarities of regional planning, using three largest cities and their suburbs as case studies. A number of negative trends have been discovered in the relations between the city and suburban area, that need to be resolved during the subsequent stages of designing to take into account the changes in the management system - decentralization and development of territorial communities that will be interacting with the city on systemic positions.

Key words: agglomeration, big city, settlement system, urban planning activities, suburban area, general plan, migration, trans-border region, group form of settlement, urbanization.

\section{Introduction}

The modern urban planning activities are closely related to the social and economic development of our society at all levels - from the state in general to a separate population center. One of the most important and difficult problems in urban planning is the one of development of local systems of populated areas in the process of change in the Ukraine's administrative and territorial structure.

Rational organization of manufacturing and environment, labor conditions, everyday life, and leisure at all levels of the settlement system will depend on resolution of this problem.

Today, the settlement system is considered to be a new stage of urban planning with the main task of uniting the problems of the city and environment due to emergence of an object - a territorial community (a local system of populated areas).

A retrospective study has shown the necessity of changes to the task complex that are to be developed at the current stage.

A necessity has been discovered to develop new methodological techniques that would unite the challenges of the city and suburban areas that constitute autonomous agents of the settlement system.

Political processes that drive changes in the planning structure development strategy at all levels of urban planning activities have an important significance as well. 
The reality is running behind fantasies and, on the contrary, leads to destruction of environment by people who do not wish to use the already urbanized territories in more efficient ways. As many other systems, the settlement in Ukraine is a notable example of failure of the existing misbalanced state structure.

"The development of interaction mechanisms between central and local bodies of executive power will depend on the scenario of political process in Ukraine among other things" (Perehuda, 2013, c. 252).

This is the paradigm that is developing today in the urban planning activities in Ukraine, that lies not in an individual character, as many have been characterizing the decentralization process, but in common interaction aimed at improving the state of affairs, not in antagonism between the city and suburban area, but in finding ways to cooperate in resolving economic, social, territorial and other issues.

Recently, special attention has been paid to large cities and their influence zone in the sphere of territory planning according to the government policy. Decentralization processes have been encouraging their territorial growth even more. This is especially relevant for cities serving as centers of regional settlement systems, such as Kyiv, Lviv, Kharkiv, Dnipro, Odesa and others. Up to this time, there have been no theoretical definitions providing a clear explanation of a big city influence zone, suburban area, urban agglomeration etc. Therefore scientific research works have been to a significant degree based on conventionality of definitions. Thus, the boundaries of an urban agglomeration have until recently been defined using a criterion of economic and planning integration of settlements, and intensity of labor bonds. The main strategy has always been to satisfy needs of the big city on the territories allocated for development, placement of manufacturing facilities that are not efficient for a city, resolution of utility requirements, and recent periods have seen extremely intensive rates of residential construction. Residential construction is less expensive compared to urban development, it is quicker to complete, has lower quality and is often antagonistic to the environment.

In modern conditions, when the industry generally no longer serves as economic base for urban planning and is losing its significance in the process of agglomerating adjacent territories, development of agglomerations is taking place according to new principles conditioned by changes in the social and economic situation, interaction between self-sustained empowered territorial communities, and territorial associations of settlement groups.

In these circumstances, it would make sense to consider agglomeration, big city, and suburban area as a zone of "common interests of the city and region", as a unified spatial entity where society's daily living activities are developed, as a group form of settlement with definition of boundaries, authorities and tasks of urban planning and regional significance.

\section{Overview of Publications on the Topic}

Наводиться The topic of architectural and regional planning has many times been raised in research works that provide rather full and deep characteristics of the period up to 2000-s. The period of Ukraine's independence has been characterized by a change in the direction of both scientific and project strategy in urban development.

The urban planning activities divided into domains that are sometimes not related to each other, which has currently resulted in many negative consequences.

Scientific activities have become more theoretic without backing of practical implementation. Project activities have become a "servant" of the customer and governance system, and therefore have no connections with scientific work. The construction industry is enjoying the position of all- 
permissiveness whatsoever. Despite the complexity of joining efforts to achieve positive results, nevertheless, scientific research in all spheres of urban planning activities deserve dedicated attention.

Scientific works of M. Diomin, O. Synhaievska, V. Vadimov, T. Panchenko, Yu. Bilokon, I. Fomin, Yu. Palekha, H. Pidhrushnyi have been dedicated to research of systemic character of settlement at all levels. In the recent years, among the works of strategic importance, the research "Territorial planning in Ukraine" by V. Kuibida and Yu. Bilokon should be noted. It asserts that "European countries already possess experience in spatial development management" (Bilokon, 2001, c. 106; Fomin, 1998, c. 6-9; Fomin, 1986, c. 112; Fomin, 1974, c. 114; Dyomin, 1991, c. 185; Kuibida \& Bilokon, 2009, 107; Palekha, 2010, c. 5-14; Dyomin, 2005, c. 102-113).

Research of historical urban-planning assessments as a result of changes in administrative and territorial structure deserve special attention. Works of M. Habrel, I. Fomin, V. Nudelman, A. Stanislavskyi and others can be classified among such research efforts.

Foreign specialists, such as V. Gropius, L. Keeble, I. Freedman, K. Lynch, D. Harvey, and P. Hall should also be mentioned.

The specific character of the Ukrainian school lies in the deep study of separate directions in regional planning in the works of I. Bystriakov, H. Pidhrushnyi, Yu. Palekha, T. Panchenko, A. Hladkyi, and M. Kushnirenko. (Kushnirenko, 2006, c. 130-154).Czech urbanists I. Musil and I. Horvatov have shown the influence of social and spatial prerequisites on the development of group systems of populated localities. In the authors' opinion, development depends not only on natural conditions, but also on motivation of people to satisfy social needs that have been forming with historical experience, "activities of people are aimed at a certain objective, that has a certain spatial regularity." (Musil \& Horvatova, 1978, c. 63-71).Considering the evolutionism in development of settlement system from the 80-ies of the XX century, the demographic factor is ceasing to play the role of natural reproduction, but acquires a principle of adjustment to the new situation.

The next factor influencing the development of the settlement system is demographics as a type of population's living activities that shapes the settlement potential.

Yu. Pivovarov, Zh. Zaionchkovska, and A. Vyshnevskyi come to the conclusion that "in the circumstances when population growth is slowing down and its spatial structures are enlarging, amplification, pulling of population to the largest cities and their suburban areas (agglomerations) means escalation of contrast in the network of urban and rural settlements in terms of size" (Zayonchkovskaya, 1985, c. 25-31). Currently, in Ukraine this process has a latent character. In the opinion of some specialists, it even has a reverse pattern - the process of depopulation or suburbanization, relocation of a proportion of urban population to the rural area. A. Dotsenko provides a number of examples of redistribution of population growth in regions. (Dotsenko, 2010, c. 529).

\section{Objective}

This publication's objective is to demonstrate transformation of evolutionary studies in the sphere of regional and urban planning, characterize the real status of suburban territories in the process of decentralization and administrative and territorial changes in Ukraine. An attempt to find positive and negative sides in the complicated relations between the city and suburbs. And to suggest a strategy for agglomerating local systems of the local level of suburban zone into unified spatial, economic and social systems as one of the reactions to the generally uncontrolled process.

To consider the developed concept of agglomeration not as a disorderly urbanization process without defined limits, but as a territorial association of local settlement systems, built on the 
principles of economic development, natural and environmental potential, and historical and cultural preservation. To outline problematic aspects in the definition of interaction between the city and suburban area, as well as to juxtapose the concepts of "suburban area", "influence zone", "common interests zone", and "agglomeration".

\section{Materials and Methods}

We are used to many processes taking place in the urban planning theory and practice. The growth of large cities, deterioration of the environment, migration of the population, devastation of territories and their common misuse constitute only an insignificant list of challenges in the current urbanization process. We have already agreed that the process of settlements agglomeration is connected with migration of the population of small inhabited localities in search of employment, better life, services, culture etc.

In theory, the city should be taking into account all the factors in its general plans - economic, social and environmental capabilities of its sustainable development. However, it is difficult to characterize this process as stable, especially in the recent times, when the process of urban advancement upon suburban territories is gaining momentum.

Frederick Lewis Allen has pointed out five main stages in the history of suburban areas development:

I-st - started in the late XIX century. With emergence of the railroad, country residents start commuting to towns for work. Inception of intensive migration processes. Distinguished development falls on 1900-1920.

II-nd - the 20-ies of XX century (emergence of personal vehicles). Construction of a large amount of country motor roads.

III-rd - 1930-1945 of the XX century - uneven and unstable situation in urban development.

IV-th - 1945-1980 of the XX century - an intensive stage driven by prefabricated construction, new materials, high demand for quickly-built accommodation.

V-th - 1980 - these days. Stratification of the society according to the level of income opens possibilities to build secondary residence in suburban areas, which significantly accelerates urbanization of suburban territories.

And this invasion is by $80 \%$ represented by residential construction, which is inconsistent, lacking combination of approaches, sporadic, and unprofessional from the urban planning and architectural perspective.

The new century has acquired from the preceding one not only high culture, science, philosophy, modern construction, industrial, and information technologies that have changed the world, opened possibilities and prospects to develop a new quality environment for human life; not only a developed network of flourishing cities, unique megapolises, infrastructure, examples of reconstructed landscapes, but also a whole number of areas that have become uninhabitable, and degraded agricultural lands as a result of poor management, exaggerated ambitions, greediness and mindless squandering of resources by humans.

Ukraine is a country with a relatively high level of urbanization: $67 \%$ of the population were living in urban settlements as of the beginning of 2000. (Kuibida \& Bilokon, 2009, c. 33-35).

Demographic forecasts that were used at that time envisaged a significant decrease in the population. And its reduction in industrially developed regions such as Dnipropetrovsk, Kharkiv, Luhansk, Odesa, and Zaporizhzhia was considered to be the main underlying reason. As of 2018, the forecasts largely came true due to a number of objective and subjective reasons. The country passed that threshold of 46 million in the downward direction. 
Before the beginning of the 70-ies of the XX century, the question of demographic character was more rhetorical than real, general plans were developed basing on the data significantly exceeding the actual figures. The analysis of region-planning works showed that they were implemented largely without taking into account the approved indicators. There appeared an idea of "complex regional planning" with developed recommendations that were approved by the State Committee for Construction of the Ukrainian Soviet Socialist Republic.

The "General Scheme of Territory Planning of Ukraine" developed by the State ScientificResearch Institute of Urban Design "Dipromisto" chaired by Yu. Bilokon became a significant achievement of the urban-planning science. In a short period of time there were developed all regional schemes of district planning, however the interest to the urban planning activities and its influence on actual planning solutions was gradually declining, and today its level is extremely low. If in the XIX century the general plan constituted a Law, at the beginning of the third millennium this is a more or less formal document that can be amended by numerous agencies and institutions, which has led to a complete loss of the entire hierarchy in projecting activities in the sphere of urban and regional planning. The state's passive attitude in enforcing compliance with the requirements of urban planning documentation has led to a collapse and territorial destruction.

So far, the main ways if its regulation are admission and gap-stopping of the consequences alongside reporting on the deterioration of the environment. Partial delegation of big city functions to the suburban area, to the influence zone, is essentially the principal part, the uncontrolled form of city agglomeration, and urbanization of new territories. Urban agglomeration is a compact multipurpose system of territorial settlements around the central city. And then, as it goes in many textbooks - the system has common production, labor, transport, recreational, cultural and social connections due to shuttle migration etc. And again, it is people's guilt to wish for a better life.

Among the ultra-complicated processes of all times, there has been the one of regulating the "city-suburb" system, which, in most cases, is turned into "intervention" of the city into the suburban area.

The suburban area is a total of administrative districts adjacent to the city forming together with it a comprehensive whole in the functional-and-planning, social-and-economic, and administrative structure. (Dotsenko, 2010, c. 529).

Suburban area is "a territory surrounding the city and sharing close functional, economic, social-hygienic, architectural and other types of interconnection and interdependence with it." (Dotsenko, 2010, c. 529).

There are two definitions, but in one of them the territory is treated as an object, and in the other one - as administrative districts. So, what is an object of the urban planning strategy in relation to the suburban area? In order to understand this let us try to look into the depth of object-generation process.

In general, the city influence zone as an object of study by different experts has always been treated in different ways. Almost everybody agrees about one thing - that these are the territories that are not subject to development, but require structural understanding, alignment as a full-fledged element in the regional planning system.

But so far, the dilemma of city - suburb, or suburb - city, territory or district, reserve or independence is creating a vast chaotic battlefield for architects, sociologists, demographists, economists, ecologists, and many other specialists.

And again, everybody is united by the fact that this is a territory or land, an object of common interests, and it constitutes the principal objective for subsequent studies. 
As a chance to save future for the cities, especially centers of settlement systems, there is the idea of decentralization that provides for regulation of systemic character of territorial organization.

It is possible to contain the uncontrolled destructive power only by a sharp amplification of governmental and public control over urban planning activities, as well as implementation of goaloriented urban planning policy. At the same time, in its turn, the legislative state activities and executive actions at the level of local systems, as it is provided for by the Law on decentralization, should be accountable to public institutions. In the process of development of urban planning solutions - and they always attract significant public attention - it is the extent to which interests of the public and individual citizens are taken into account that should define quality of an urban planning project.

The relevance of urban planning operations in Ukraine is determined by a high concentration of population in the nine largest cities and its sharp reduction in small and medium ones. The situation is especially catastrophic in the influence zones of large cities, where economic capabilities for growth have been lost not only by rural settlements, but also by small towns that used to be the centers of recreation, culture, history etc. If earlier suburban area used to be a zone for possible improvement of accommodation for large city residents, today the suburban area is filled with residential housing by migrants that choose a big city seeking to improve their subsistence.

Going back to the history of the suburban area, this issue has always been emerging when further city development prospects were considered. And it always happened that the city, having grabbed a piece of territory, was yet again living its own life until the next general plan, having forgotten that territories are not infantine.

The discussion about the city and suburbs, to be more precise, of the opinion that the city cannot exist on its own gained traction back in XIX century, when the ideas of "ideal cities" and "utopian cities" appeared (E. Howard, S. Fourier, R. Owen, A. Saint-Simon, T. Granier et al).

In the late XIX century, disputes of urbanists and de-urbanists were gaining momentum. A city or a system of settlements, total urbanization or strict delimitation of urban and rural territories.

A considerable contribution into the study of relations between the city and suburban area was made by well-known scientists of the German urban planning school and social economy: A. Weber, W. Christaller, I. Thünen, and A. Lösch.

The essence of Christaller's pattern consists in minimizing the average distance of trips to the central cities. Central cities are maintaining not only themselves, but also the population belonging to its district (suburban area).

A. Weber took two main functions as the basis of the correlation - manufacturing and transport.

W. Launhardt considered transport to be the principal factor, the basis of all connections. The theory of A.Lösch is of a special interest; he united the doctrines of Christaller and Thünen and came up with a concept named the "economic landscape".

The subsequent theories were linked to various attempts to unify or divide the existing ones, however, they were only heating up the interest towards future discussions on regional planning and inception of the process of agglomerating settlements, and research of interrelations in the "citysuburbs" system.

This gave rise to a number of concepts linked to the processes of interaction between the city and suburb, in particular:

1990 J. Garreau - the concept of "edge city", concentration of business and trade activities in the suburban area. 
2003 Robert Long - discovered a new form of urbanization - "endless cities". Spread of office development beyond the borders of the real city.

1997 T. S. Stieverts - the "(in)between city"; Soja - "exopolis"; Herrington - "outer cities"; Lehrer - "flexspace"; Bloch - "the Inverted Metropolis".

1998 Baccini and Oswald - used the term "netzstadt" (networked city) and "patchwork city". 2003 Eisinger and Schneider - "urbanscape".

In 2005, the term "metrourbia" appeared, the absence of borders between the city and suburb.

The urban planning theory acquired significant changes with the emergence of the new socialistic social structure of the society. The desire to improve everything at once had both positive and negative consequences.

These were the specialists of Ukrainian urban planning school who suggested to study the new city not as a separate element, but as an element of a system with clearly defined influence zone. This was exemplified by the "new socialist cities" with a radius of adjacent territories up to $12 \mathrm{~km}$ that were functionally linked with the city. The 30-ies - 40-ies, the functionality paradigm encompassing not only cities, but also entire regions (fig. $1 \mathrm{~A}, \mathrm{~B}$ ).

The problem of suburban areas emerged in the USSR with a renewed intensity in the 50-ies of the XX century, when it was necessary to rebuild the cities destroyed by the war. The suburban area was becoming the new resource base for the city in terms of territory, human resources, food etc.

In 1962, for the first time, a resolution was adopted on development of suburban areas for all USSR cities, however, at that time, the theoretical grounds for distinguishing suburban areas was absent, and it has no clear-cut methods, calculations or standardized boundaries up to this time.

It was believed that such zones are necessary only for large and the largest cities with especially high growth rates. The city of Leningrad was the first to encounter the challenges of the city and suburban area, there was a problematic necessity to settle a 700 thousand population, powerful industrial facilities, research and development enterprises etc.

In the preliminary regional plan of 1951-1952 for the Kyiv suburban area, the settlement of 150 thousand residents connected with the city was considered as a territory reserve.

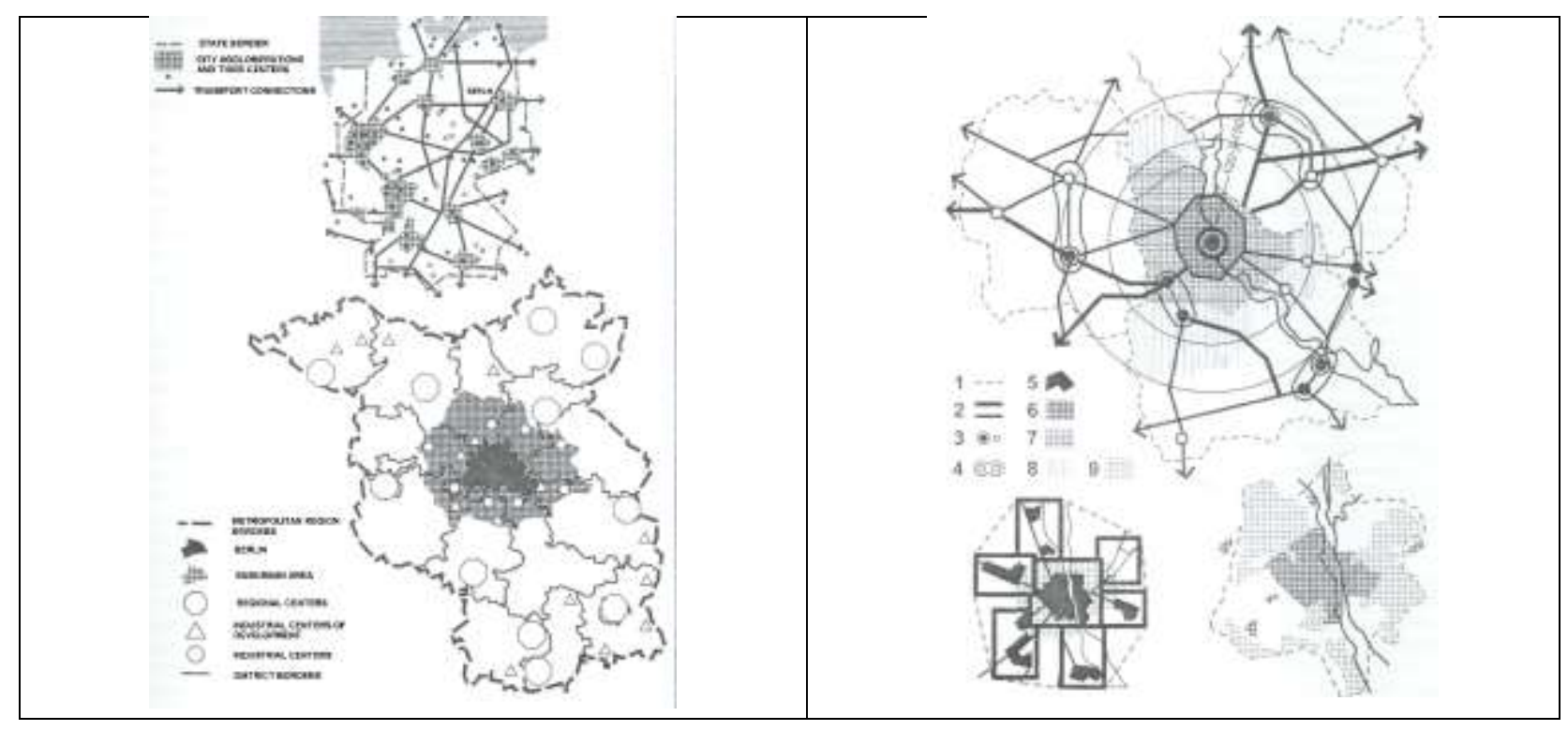

Fig. 1 A, B Development of Suburban Areas: Berlin (A), Kyiv (B) 
According to the Regional Plan draft, the suburban area was to provide the city with food products, locations of organized leisure in the green belt and on the Dnipro, Desna, and Irpin rivers. There was a complicated task to resettle part of the territories that were planned for flowage by the Kyiv Cistern.

When the Riga suburban area was planned, alongside the settlement of population, location of agriculture, and city residents' leisure, there also emerged the challenge of developing a resort area of national importance on the Riga coast line.

In the course of development of industrial cities in the Donbas region the suburban area acquires peculiar traits. Emergence of new cities and development of the existing ones reduced the distance between cities down to $15 \mathrm{~km}$.

In these regions, the planning of suburban zones is becoming an area of common interest not for a single city, but for a system of populated areas, agglomerations.

The 70-ies and 80-ies were the period of exacerbation of environmental problems engendered by excessive development of industrial enterprises.

Growth of the cities is leading to conflict situations between the city and adjacent territories, once again raising the issue of delimitation and attempts to carry on activities and development independently.

There emerge a range of problems in the social, environmental and economic domains:

- inequality of income of people in the suburban area and city;

- difference in maintenance of systemic services;

- difference in provision of transportation;

- loss of economic potential of existence;

- functional imbalance in land use planning and management;

- under the pretext of reformation, the existing structure is being overloaded, and thus pushed beyond the regular process of existence;

- invasion upon the nature occurs on the both sides - from the cities - as a result of urbanization, and from the suburbs by disregarding the farming standards, wasting natural resources, attempting to improve the situation by squandering lands, forests, water reservoirs, subsoil etc.;

- the city and suburbs are "speaking" different languages, as a result, it narrows down to trading, mostly the lands, guided by the principle "I need this, and what's in it for me".

It is possible to provide many more examples of the conflict situation that makes everyone suffer, therefore, the principal objective for the specialists is to try to understand, analyze, and not to "develop", but to agree upon common activities. Not a movement towards a conflict, but a parallel and prospective development, instead of creating problems.

An attempt of "common interests" territory zoning may be one of the directions, namely, to apply the belt system.

Thus, according to I. Gunen, considering the agricultural sector of suburban territories, each crop should be located at the optimal distance from the market. As a result, the author predicts six concentric belts by agricultural specialization. (Dotsenko, 2010, c. 529). Studying the conditions of agglomerations formation around the largest cities of Ukraine in the direction of agricultural and industrial complex specialization, S. Ishchuk and O. Hladkyi offer three specialization belts formed on the basis of highly marketable and intensive production.

Two-belt zoning is the most discussed in the field of industrial relations. This is a city reserve area and a peripheral zone, which usually coincides with the conditional boundaries of agglomeration and is measured by the time needed to access the central city. 
Most theories use not the functional capacity of the territories, but the time as a constant of distance to a particular object. Travel time to work (1-1.5 hours), distance up to $60 \mathrm{~km}$ for large cities, expenses for weekend trips, needs of household services and cultural events. Everything is based on the time spent for comfortable trips of the population's pendulum migration. Unfortunately, the time factor is increasingly proving its devastating impact on the city environment.

Deterioration of the environment, and absorption of suburban areas by cities are more relevant for the current situation, so there should be developed a strategy for interaction of all the stakeholders. Such structural chains can be: government institution - communities - business science - education - public interest - manufacturing.

Rules and restrictions must be set for these structures to operate, and again this should be done with the help of zoning. Zoning should be carried out by normative, legal, ecological, social and economic opportunities of territories. In this case, the suburban zone becomes not only the sphere of activity for one city, but also the sphere of interests of several entity-cities whose suburban zones intersect.

In the conditions of settlement, the suburban area can be common for several inhabited localities and should take into account the interests of all stakeholders both in the process of urban planning documentation development and its approval.

The territorial-suburban zone may be divided into four sub-zones with varying degrees of reciprocal regulation together with the city: I. Internal zone R - $25 \mathrm{~km}$; II. Intermediate zone R 25-50 km; III. External zone R - up to $100 \mathrm{~km}$; IV. Territories of common interests.

The Internal zone with $\mathrm{R}-$ up to $25 \mathrm{~km}$.

It is the zone of agreed interests of the city and suburbs in the all spheres of development.

The zone provides for common conditions of reservation of residential construction areas, service system, transport support with organization of connection hubs, recreational services to ensure short-term recreation for residents of the city and suburbs, industrial branches of the main enterprises of the city.

Urban planning documentation of all zone stakeholders is subject to mandatory coordination with the developed suburban area project.

The Intermediate suburban area $\mathrm{R}-25-50 \mathrm{~km}$ meets the time availability according to the agglomeration criteria.

This is the zone of possible and priority development of existing new parallel cities as subjects of industrial decentralization. The zone provides for industrial, recreational, research, specialized, and healthcare activities, as well as location of gardening and suburban cooperatives. The Intermediate zone is a potential factor in reducing migration processes of the city.

External zone $\mathrm{R}$ - up to $100 \mathrm{~km}$.

This zone serves as a peripheral part of urban agglomeration territories, which includes recreational objects of long-term leisure, agricultural enterprises, provision of the city with products, specialized production, scientific, and medical facilities.

The territories of common interests have no clear boundaries. They are formed along the main transport corridors and occupy the first and part of the second zone.

And yet, in order to "divide" it is necessary to "limit" first, at the initial stage, to make limitations by territorial, legislative and regulatory criteria.

Despite the above-mentioned, the boundaries cannot be permanent, and in each specific case, existing social and economic situation on a territory, inhabited localities, settlement systems, 
functional direction of development, level of urban development, capacity and interests of communities should be taken into account.

Setting the boundaries of suburban areas is important, but almost impossible according to today's principles, requirements and urban planning regulations.

The boundaries are constantly changing due to development of the city, so most probably, the territorial factor cannot constitute an objective limit.

The Kyiv agglomeration is the largest one in Ukraine, and could eventually form a single metropolis with Odesa, another city with a million-plus population. The combination of administrative functions with the functions of Odesa (port, sea, recreation...) in a single metropolis could give a significant impetus to the development of the settlement system and its transition to a higher level. The population of the Kyiv agglomeration was predicted to reach 3.0-3.2 million of residents in 2020. (Kyivproekt JSC, 2002). The Kyiv agglomeration presents the same trends as most major agglomerations of the world: rapid population growth, decline of manufacturing and industrial sphere, increasing social and environmental issues. All this required rather regular and frequent development of the urban planning documentation in order to adjust the situation to the growth of both agglomeration and the city itself. (Table 1)

Main Works on the Development of Kyiv and Kyiv Agglomeration. Table 1.

\begin{tabular}{|c|c|c|}
\hline Years & Types of design works & Main Implementing Organization \\
\hline $1934-1936$ & Kyiv General Plan Design & - \\
\hline 1946-1949 & Kyiv General Plan Design & - \\
\hline 1967 & Kyiv General Plan Design & $\begin{array}{l}\text { KyivProekt, Kyiv Scientific } \\
\text { Research and Design Institute of } \\
\text { Urban Planning } \\
\text { "KyivNIIPmistobuduvannia" }\end{array}$ \\
\hline 1967 & Kyiv Suburban Area Design & $\begin{array}{l}\text { State Scientific-Research Institute of } \\
\text { Urban Design "Dipromisto" }\end{array}$ \\
\hline $1970-1982$ & $\begin{array}{l}\text { District Planning Scheme of Kyiv } \\
\text { Region }\end{array}$ & $\begin{array}{l}\text { Kyiv Scientific Research and } \\
\text { Design Institute of Urban Planning } \\
\text { "KyivNIIPmistobuduvannia" }\end{array}$ \\
\hline 1976-1978 & $\begin{array}{l}\text { District Planning Design of Kyiv } \\
\text { Influence Zone }\end{array}$ & Kyivproekt \\
\hline 1974-1979 & $\begin{array}{l}\text { Regional Settlement Scheme on the } \\
\text { Territory of Ukraine }\end{array}$ & $\begin{array}{l}\text { Kyiv Scientific Research and } \\
\text { Design Institute of Urban Planning } \\
\text { "KyivNIIPmistobuduvannia" }\end{array}$ \\
\hline $1980-1982$ & $\begin{array}{l}\text { Technical and Economic Feasibility } \\
\text { Study of the Kyiv General Plan }\end{array}$ & Kyivproekt \\
\hline $1983-1986$ & Kyiv General Plan Design & $\begin{array}{l}\text { HolovKyivProekt (Design } \\
\text { organization of the city of Kyiv) }\end{array}$ \\
\hline 1986 & $\begin{array}{l}\text { Regional Settlement Scheme on the } \\
\text { Territory of Ukraine for the Period up to } \\
2000\end{array}$ & $\begin{array}{l}\text { KyivNIIPmistobuduvannia, } \\
\text { Dipromisto }\end{array}$ \\
\hline $1985-1987$ & $\begin{array}{l}\text { General District Planning Scheme of } \\
\text { Kyiv Region }\end{array}$ & $\begin{array}{l}\text { KyivNIIPmistobuduvannia, } \\
\text { HolovKyivProekt }\end{array}$ \\
\hline
\end{tabular}


1999-2001 Kyiv Development Concept

2001

1999-2002

1999-2002

1997-2002
General Planning Scheme of the Territory of Ukraine Kyiv General Plan Design

\section{Kyiv Suburban Area Design}

General Planning Scheme of the Territory of Ukraine
Kyivgenplan Institute, OJSC

Kyivproekt

Ukrainian State Institute of Urban

Design "Dipromisto"

Kyivproekt Institute,

OJSC Kyivgenplan

Ukrainian State Institute of Urban

Design "Dipromisto"

Ukrainian State Institute of Urban

Design "Dipromisto"

Today, in the strategy of creation of administrative-territorial communities as independent elements of settlement system, the city is forced to look for new approaches, in particular, attempts not to consider the city and suburban area in general, but regard it as an association of social and economic entities - territorial communities (group settlement systems at the local level). This approach most definitely corresponds to the term "planning of regulated development of urban agglomerations" introduced by I. Fomin in his work "Urban agglomeration planning (designing methodology)" as an opposite to the process of spontaneity and intensification of uncontrolled urbanization.

According to the last general plan of Kyiv (2002), which considered the city and suburban area comprehensively, the main tasks were as follows:

- improvement and further development of functional and planning structure that corresponds to the new status of Kyiv as the capital of an independent sovereign state;

- overcoming negative demographic trends in the acceleration of natural population growth and escalation of migration processes;

- the suburban area of Kyiv was defined as a new single administrative entity - "Kyiv Capital District".

This approach provided for an opportunity to achieve a more unified social, economic and territorial structure and ensure a more coordinated development of Kyiv and its area of influence.

According to the general plan, the expansion of the city territory was to be carried out at the expense of the adjacent territories in accordance with the project prospective proposals, thus forming the Kyiv capital district. (Fig. 2)

The second largest city of Kharkiv deserves no less attention as an urban agglomeration center. Powerful manufacturing, cultural, and scientific center, which forms a large urban agglomeration in terms of area, that includes several small and medium-sized towns. Like Kyiv, in 2002 Kharkiv began developing a new general plan that was prepared by the Ukrainian State Scientific and Research Urban Design Institute "Dipromisto".

The first results of the study revealed a number of negative phenomena similar to Kyiv, namely:

- negative demographic trends, population decline in general and a sharp reduction in the working age population;

- migration processes have led to an increase in population that was not employed in social production, which creates a burden on the existing infrastructure unforeseen by the calculations of the general plan; 
- the unregulated development of the agglomeration is gaining an uncontrolled pace, namely the development of group forms on the basis of small towns, which creates environmental and other problems.

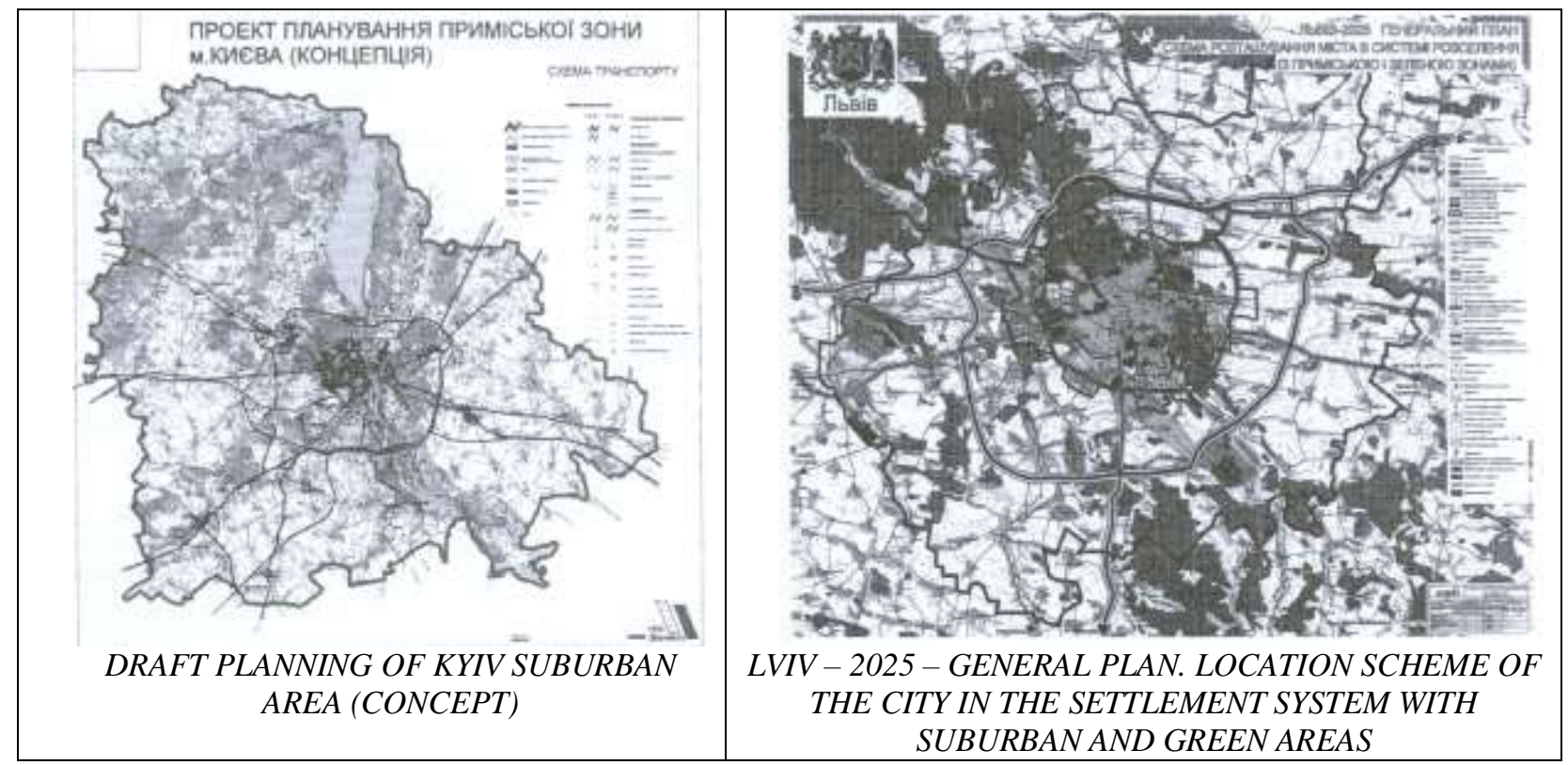

Fig. 2 Boundaries of Kyiv and Lviv suburban areas

If the first two phenomena have a more social character, the third one has forced to offer a new approach to viewing the city and suburban area. In determining the city influence area, a ranking of administrative districts was carried out and individual groups were singled out, which include districts with different social and economic indicators. Analyzing the Kharkiv city agglomeration, it is expedient to compare some indicators with the Kyiv one according to the general plans of OJSC Kyivproekt and the Dipromisto Institute. (Table 2) As a result of the comparison, a method of analysis and mapping of indicators was proposed, which took into account three groups of indicators:

Business activity;

Social issues, recreational activities;

Transport and engineering communications.

Comparative characteristics of urban agglomerations. Table 2.

\begin{tabular}{lccc}
\hline & Kyiv & Kharkiv & Lviv \\
\hline $\begin{array}{l}\text { Area of the localities group } \\
\text { system }\end{array}$ & $13,800 \mathrm{~km}^{2}$ & $10,800 \mathrm{~km}^{2}$ & $\begin{array}{c}12,120 \mathrm{~km}^{2} \\
55 \% \text { of the } \\
\text { territory }\end{array}$ \\
Population of the central city & & & 982 thousand \\
& $\begin{array}{c}2.6-3.0 \\
\text { million }\end{array}$ & 1.470 million & people
\end{tabular}

The analysis according to these indicators allowed to confirm the size of the city influence zone in temporal availability of 60-90 minutes.

According to the geopolitical situation, the Lviv agglomeration should be determined by similar characteristics. The main factor being the border area and dependence on international 
transport corridors, cities of regional importance, in the long run it is a contender for development of a territorial areal.

As a result, it can be argued that cities such as Kyiv, Kharkiv, Lviv and others actualize, transform and sell products used by the society, which allows them to exist. However, in order to dynamically develop, central cities of regional systems have the opportunity to rely on an effectively functioning living environment, which in its turn is able both to use the product of the city as well as to support and develop social and economic interaction with it.

The processes of decentralization in Ukraine and the formation of a new structural regional unit of the territorial community (in social terms) and as a local system of inhabited localities at the local level (in the urban planning sense) are endowed with properties through which the agglomeration will become a union of local systems and acquire more reasonable territorial boundaries and systemic ordering.

It is the ordering of city-forming connections of the local level of local systems, communications in accordance with the fundamental laws of social development and spatial settlement of people that is one of the principal tasks of determining the development strategy of local systems (territorial communities).

Agglomerations in this case are a factor in the organization of the influence zone group systems of large cities while influencing the nature of development of the city itself.

We have passed the period when the suburbs were inhabited by people with great wealth, now the settlement of the impoverished is increasing, filling free spaces, and increasing the burden on the territory.

The city needs a large number of workers for low-skilled jobs, which are mainly done not by city and suburb residents, but by the newcomers.

This category also most often finds its settlements in the suburbs. Here, the low-cost housing demand was also picked up by investors, and a lot of so called "social housing" appeared, which in fact has nothing to do with the term. This is just housing of the lowest standards like a dormitory and almost without services, like schools, kindergartens, except for food stalls.

The process, which has inconspicuously slipped into Ukraine, is gaining enormously terrible proportions, and the results will be very disappointing in the near future. The city creates an "environmental shroud" around itself, depriving of the opportunities for development, recreation, and clean air.

The displacement of low-income families from the city to the suburbs was called a "demographic inversion".

The practice of American cities has shown that the transformation of suburbs into slums is typical for all large cities.

The costs of housing, cars, education, medicine, and food are the highest for the society. A resident of the suburbs is either at the urban level or lower in all respects. Over time, consciousness will force a change in the attitude towards suburban existence, especially among young people, who require closer communication in the work-housing-leisure framework. These three parameters are trying to occupy 24 hours of a modern young person's day and there is no time for transportation.

Another problem of intensive development of the housing in suburbs is the lag of construction works behind the needs. What does this mean? This means the fact that all housing, which is already planned or under construction, will lose the factor of modernity tomorrow and the day after tomorrow. And this is the problem of investors who ignore this fact for the sake of profits. We have an opportunity to wait until there is a lot of housing in the suburbs for which there is no demand, and the territories are lost. 
According to research by American scientists, suburbanization has a large number of vulnerabilities. The crisis of environmental policy is reducing the wealth of the middle class, which is the main user of the suburbs. In this case, they are forced to leave suburban housing, which often exceeds the their needs.

George Galster, a professor of urban planning at Wayne University, points out that "if the number of the poor in a neighborhood or city exceeds $15-20 \%$, then the hell breaks loose and all the troubles come together - the crime situation gets worse, the school dropout rate, teenage pregnancy, drug addiction are on the rise, but the housing prices in the area are falling".

Suburbs are mostly inhabited by the middle class and the poor. The middle class relocates to town houses often due to declining incomes. They start renting their own houses to several families thereby increasing the percentage of the poor. Population density is increasing, while the maintenance services, economy, and utilities are not designed for this.

The agglomeration becomes a factor of external influence, which largely dictates the conditions of the system operation forcing it to adapt to the city conditions and requirements. This influence is especially evident in the suburban area, where territorial communities have essentially lost their historical identity in economic development.

Development of the compensatory capabilities for the both subjects should become one of the ways to adapt the impact of the large city agglomeration forces and reactive changes in local level systems in order to maintain their structure. Otherwise, the lower level system (territorial community) will be forced to make a phase transition, changing its structure and nature of functioning. With too rapid and significant changes in the external environment, the local level system may totally collapse, and the territorial community may be disbanded or attached to another system.

\section{Results and Their Discussion}

The result of the study is an attempt to consider the relationship of the city and the surrounding territory not from the standpoint of suburbanization, which has gained significant momentum in Ukraine, but from the standpoint of a strategic joint process of streamlining all factors: economic, political, environmental etc. Management decentralization processes are an efficient tool for implementing this strategy. And in the process of reform, it is important to realize the insufficiency of scientific and legislative framework, or rather the imbalance in their operation.

It is an attempt to identify the main strategic aspects that may subsequently be introduced into the process of forming the relationship of the city and surrounding territories. It is also an attempt to avoid distribution of responsibilities, but to consolidate economic potentials, natural resources, social desires, demographic situation and political will to form decentralization processes and a new administrative system based on the rights of laws in accordance with regulatory requirements.

It is an attempt to identify the real situation in the settlement system, which acquired negative traits during the years of independence, that constitutes the task requiring to restore the legal, legislative, and executive role of urban planning activities.

\section{Conclusion}

In the urban planning context, the agglomeration or system of urban-suburban area is the object of planning and design of interconnected functioning and development of settlements that are part of the system of inter-settlement territories, infrastructures and therefore, to understand the object it is crucial to determine its boundaries. The program of decentralization and the new administrative-territorial system, the organization of independent empowered territorial 
communities, in fact, is an attempt to define boundaries, to create associations of agglomeration relations based on the state of opportunities, desires from a particular person to the state program.

To move from the desired trend to the agglomeration realized in the urban planning sense as an association of systems, it must receive physical boundaries, which will allow it to become an object of management, adjacent territories, taking into account the sufficient theoretical and practical experience of Ukrainian theory and practice of urban and regional planning. However, due to frequent changes in the social and political situation, the process of streamlining the territorial relations between the city and suburbs is chaotic. The chaotic character is reflected in the functional imbalance, environmental overload, lack of reconstructive processes in the engineering and transport systems, increased migration processes, low employment rates, and uneven social security. It is the strategy of the systematization principles complex that is able to improve the existing situation and implement a new strategy in the development of local settlement systems at the local level.

\section{References}

Bilokon, Yu.M. 2003. Regional planning (Essence and significance). Kyiv: Ukrarkhbudinform. [In Ukrainian].

Dotsenko, A.I. 2010. Territorial organization of settlement (theory and practice). Kyiv: Phoenix. [In Ukrainian].

Dyomin, M.M., 2005. General methods of metropolitan territories development in Ukraine. Scientific-technical collection "Urban planning and spatial planning". K.: KNUBA, 21, pp. 102113. [In Ukrainian].

Dyomin, N.M. 1991. Development management of town-planning systems. Kyiv: Budivelnyk. [In Ukrainian].

Fomin, I. O. 1986. The city in the system of settlements. Kyiv: Budivelnyk. [In Ukrainian].

Fomin, I.O., 1998. Historical periodization of urban planning theory in Ukraine (20-40-ies). Regional problems of architecture and urban planning. Odesa: Astroprint, 2, pp. 6-9. [In Ukrainian]

Fomin, I.O. 1974. Urban development in industrial areas. Planning aspects. M.: Stroyizdat. [In Russian].

Kyivproekt JSC, 2002. General plan of the city of Kyiv for the period up to 2020. The main provisions. Kyiv: KIGA. [In Ukrainian].

Glazychev,V.L. 1986. The evolution of creativity in architecture. M.: Stroyizdat. [In Russian].

Kuibida,V.S., Bilokon, Yu.M. 2009. Territorial planning in Ukraine: European measures and national experience. Kyiv: Logos.

Kushnirenko, M.M., 2006. History of planning regulation of the Kyiv Agglomeration development. Experience and prospects of city development in Ukraine. Kyiv: Dipromisto, 10, pp. 130-154. [In Ukrainian].

Musil, I., Horvatova, I., 1978. Social and spatial prerequisites for development of the localities group systems. Principles of development of the localities group systems. M.: Stroyizdat, pp. 6371. [In Russian].

Palekha, Yu.M., 2010. Defining suburban areas of large cities - an urgent urban problem of today. Experience and prospects of development of cities in Ukraine. Kyiv: Dipromisto, 18, pp. 514. [In Ukrainian].

Perehuda, Ie.V. 2013. Executive power in Ukraine. Political and legal aspects of modernization. Monograph. Kyiv: Logos. [In Ukrainian]. 
Panchenko, T.F. eds., 2001. Urban planning. Designers Guide. Kyiv: Ukrarkhbudinform. [In Ukrainian].

Zayonchkovskaya, Zh.A., 1985. Some directions of settlement evolution. Regional development and management. M., 1985, 5, p. 25-31. [In Russian].

Віктор Яценко

Професор кафедри ландшафтної та туристично-рекреаційної архітектури Київський національний університет будівництва і архітектури, Київ email: murchik55@ukr.net ORCID: 0000-0002-6054-729X

\section{АГЛОМЕРАЦЙНН ПРОЦЕСИ ЗБАЛАНСОВАНОГО РОЗВИТКУ ПРИМІСЬКИХ ТЕРИТОРІЙ ВЕЛИКИХ МІСТ УКРАЇНИ}

(C) Яиенко В. 2020

Стаття $є$ результатом аналітичного дослідження формування взаємовідносин між містом та приміською зоною. Спроба визначити головні фактори, які можуть бути закладені в майбутню стратегію збалансованого розвитку та уникнути ряду негараздів при формуванні групових форм розселення в зоні впливу великих міст. Процеси децентралізації системи управління с соціальноекономічним потенціалом створення системи спільних інтересів розвитку, а не руйнування як міст так $і$ приміської зони. В матеріалах дослідження проаналізовано сучасний стан містобудівної діяльності в Украӥні, а саме особливості регіонального планування на прикладі трьох найкрупніших міст та їх приміських територій. Виявлено ряд негативних тенденцій у взаємодї міста та приміської зони, які необхідн вирішувати на подальших етапах проектування враховуючи зміни системи управління - децентралізацію та формування територіальних громад, які будуть взаємодіяти з містом на системних позиціях.

Ключові слова: агломерація, велике місто, система розселення, містобудівна діяльність, приміська зона, генеральний план, міграція, транскордонний регіон, групова форма розселення, урбанізація. 